Magdalena Żakowska

http://dx.doi.org/10.18778/8088-635-3.01

\title{
Nieśmiertelne stereotypy i współczesne europejskie imaginaria tożsamości zhiorowej
}

\begin{abstract}
W niektórych krajach traci na znaczeniu kwestia narodowa, umacniają się postawy internacjonalistyczne, lecz nasilają problemy tożsamości. [...] Mamy globalizację i lokalizację. $Z$ jednej strony powstaje infrastruktura globalnej wspólnoty, $\mathrm{z}$ drugiej pragnienie utożsamienia $\mathrm{z}$ lokalną społecznością. Nie każdy może czuć się obywatelem świata. Ale każdy musi być jakoś zakorzeniony.
\end{abstract}

Edmund Lewandowski

Współczesny świat jest ubogi w mity, przynajmniej z pozoru.

Mircea Eliade

W latach pięćdziesiątych ubiegłego wieku Mircea Eliade stwierdził z przekąsem, że nawet racjonalni ludzie Zachodu nie mogą obyć się bez pewnej postawy mitycznej. Powołujemy się na przeszłość, oddajemy cześć hymnom i flagom, święcimy bohaterów, poddajemy się porywom wzruszeń zbiorowych ${ }^{1}$. Więcej nawet: to właśnie my, Europejczycy, wymyśliliśmy pojęcie narodu, współcześnie zaś, szczególnie w Europie Środkowej i Wschodniej, przeżywamy renesans idei państwa narodowego ${ }^{2}$.

Niniejsza praca systematyzuje wieloaspektowe spektrum problemów związanych z nacjonalizmem, przemianami polityczno-kulturowymi, a także stereo-

\footnotetext{
${ }^{1}$ M. Eliade, Mity, sny i misteria, thum. K. Kocjan, Warszawa 1994, s. 14.

${ }^{2}$ E. Lewandowski, Pejzaż etniczny Europy, Warszawa 2004, s. 45-46.
} 
typami i uprzedzeniami w relacjach międzyetnicznych, stymulowanymi między innymi przez mity historyczne na obszarze postradzieckim oraz w Europie Zachodniej i Środkowej.

\section{Zrozumieć Sfinksa}

W części pierwszej monografii poddano analizie fenomen wielokulturowości, kształtowania tożsamości zbiorowych oraz przyczyn i skutków funkcjonowania światopoglądu opartego na idei opozycji, czy wręcz wrogości między „cywilizacją rosyjską” a „światem zachodnim”.

Autorka rozdziału pierwszego, dr Olga Nadskakuła-Kaczmarczyk, omawia problematykę opozycji niesystemowej (zwanej również pozasystemową) we współczesnej Rosji, a zwłaszcza sposób konstruowania przez elitę kremlowską jej wizerunku jako wroga wewnętrznego, wichrzyciela porządku i zdrajcy ojczyzny. Rozważając kontekst polityczny i społeczny, w jakim powstawały, umacniały się i wciąż powielane są wspomniane obrazy i wyobrażenia, dotyczące osób i ugrupowań opowiadających się przeciwko szeroko rozumianemu obozowi władzy, uosabianemu przez Władimira Putina, badaczka odwołuje się do teorii gnozy politycznej w znaczeniu, jakie zostało jej nadane przez niemiecko-amerykańskiego filozofa Erica Voegelina. Autorka su gestywnie dowodzi, że dyskurs elity kremlowskiej, oparty na binarnych strukturach myślenia kategoriami „swój-obcy” i prowadzący do narastania wśród Rosjan przekonania o osaczeniu ich ojczyzny przez wrogów, zarówno tych zewnętrznych, jak i wewnętrznych, ujawnia wiele cech wspólnych $z$ postawą ideologiczną opartą na gnozie politycznej, czyli systemie myślenia, wykluczającym pluralizm światopoglądowy i przypominającym, „świecką religię ${ }^{3}$.

To właśnie ze względu na stosowanie wspomnianej logiki, twierdzi badaczka, ideolodzy Kremla nie wahają się wysuwać tez, iż fakt odwoływania się przez przedstawicieli opozycji niesystemowej do wartości, takich jak demokracja i liberalizm, dyskredytuje ich zarówno jako ludzi zapatrzonych w obce wzorce, jak również jako degeneratów, przesiąkniętych charakterytycznym dla świata zachodniego moralnym zepsuciem. Na uwagę zasługują również spostrzeżenia autorki dotyczące głębokiego ugruntowania w społeczeństwie rosyjskim nastrojów antyzachodnich, wręcz ich zakorzenienia w rosyjskiej historii, mentalności i psychice. Nienawiść do Ameryki i ,piątej kolumny” nie jest wynikiem propagandy, lecz odczuwanej przez Rosjan potrzeby kompensacji gniewu wywołanego traumą związaną z rozpadem ZSRR. Po okresie, który nazwać można czasem wyparcia, negowania prawdy o nowej rzeczywistości poradzieckiej, społeczeń-

\footnotetext{
${ }^{3}$ Więcej o gnozie politycznej przeczytać można w monografii Gnoza polityczna, red. J. Skoczyński, Kraków 1998.
} 
stwo rosyjskie wkroczyło w etap rozczarowania i gniewu, sprzyjającego rozprzestrzenianiu syndromu „oblężonej twierdzy” oraz wyrażaniu wrogości, a nawet nienawiści wobec różnych kategorii zdemonizowanych „obcych”.

Nie sposób nie zgodzić się z diagnozą autorki, iż jeśli chodzi o mechanizm funkcjonowania wspomnianego fenomenu, postacie konkretnych wrogów mają znaczenie drugorzędne. Zarzuty, narracje i emocje przerzucane są stosunkowo płynnie z jednej kategorii „obcych” na drugą tak, iż zależnie od okoliczności na celowniku mogą znaleźć się tak różne kategorie „wrogów” jak migranci z Azji Środkowej, Amerykanie, państwa Unii Europejskiej, prowodyrzy „kolorowych rewolucji”, czy wreszcie rodzimi demokraci - przedstawiciele „piątej kolumny”.

Wspomniane rozważania doskonale wpisują się w powracające od lat i wciąż aktualne dyskusje dotyczące mentalnego dziedzictwa Rosji sowieckiej i stworzonego przez nią nowego człowieka. W ostatnich latach fenomen ten opisany został m.in. przez białoruską noblistkę Swietłanę Aleksijewicz w książce Czasy secondhand. Zauważa ona, iż homo sovieticus lub sowek, jak mówią o nim Rosjanie, wyhodowany w laboratorium marksizmu-leninizmu, naznacza wciąż swym mentalnym piętnem psychikę postradzieckich społeczeństw. Aleksijewicz, pisząc o mrocznej stronie sowieckiego dziedzictwa, stawia bezlitosną diagnozę przedstawicielom pokolenia dzieci, wyznawców i ofiar komunizmu, stwierdzając, iż miejsce dawnej wielkiej idei zajęła w ich umysłach gorycz, poczucie pustki oraz nowe, groźne demony:

Jesteśmy pełni przesądów i nienawiści. Wszystko bierze się z tego samego źródła, co Gułag i straszliwa wojna. Kolektywizacja, rozkułaczenie, deportacje narodów... [...]. Odradzają się stare idee: wielkiego imperium, żelaznej ręki, własnej, odrębnej drogi Rosji... Przywrócono hymn radziecki, istnieje komsomoł, tyle że nazywa się „Nasi”; jest i partia władzy, kopiująca partię komunistyczną. Prezydent ma władzę sekretarza generalnego. Absolutną. Funkcję marksizmuleninizmu zajęło prawosławie.... ${ }^{4}$.

Roman Bäcker słusznie zwraca uwagę na fakt, że cała rosyjska scena polityczna posiada odmienną niż na Zachodzie, naznaczoną przeszłością specyfikę. Podczas gdy w europejskiej myśli politycznej problemy religijne oraz kwestie związane $\mathrm{z}$ boskim charakterem władzy straciły na znaczeniu już $\mathrm{w}$ epoce Oświecenia, filozofia i historiozofia rosyjska w pierwszej kolejności skupia się właśnie na problematyce historycznych przeznaczeń oraz głębokich sensów, jakimi Najwyższy naznaczył więź między carem i jego ludem oraz, w jeszcze większym stopniu, między carem a Bogiem. $O$ ile europejska myśl polityczna czołowe miejsce poświęca kwestiom takim jak prawa człowieka i obywatela, w myśli

\footnotetext{
${ }^{4}$ S. Aleksijewicz, Czasy secondhand. Koniec czerwonego człowieka, Wołowiec 2015, s. 8, 16.
} 
rosyjskiej rozpatrywane są one nade wszystko przez pryzmat rozważań dotyczących szans na odbudowanie dawnego imperium oraz na temat statusu państwa rosyjskiego w świecie ${ }^{5}$.

Wspomniany sposób myślenia znajduje odzwierciedlenie m.in. w narracjach obecnych $\mathrm{w}$ rosyjskich podręcznikach historii. W podsumowaniu obowiązującego obecnie podręcznika do nauki historii najnowszej, przeznaczonego dla uczniów 9 klasy, znajduje się między innymi następująca diagnoza sytuacji politycznej przed i po wstąpieniu na fotel prezydencki Władimira Putina:

Radykalne reformy, w ramach których dokonywało się przejście do gospodarki rynkowej oraz tworzono demokratyczne instytucje władzy, miały przebieg trudny i bolesny. W ich konsekwencji nastąpił rozpad sfery zabezpieczeń socjalnych, polaryzacja stopy życiowej mieszkańców, osłabienie wszystkich instytucji państwowych, kryminalizacja ludności. Dążenia separatystyczne stały się poważnym zagrożeniem dla bezpieczeństwa Rosji oraz dla wartości leżących u podstaw funkcjonowania państwa. Dopiero na początku XXI wieku udało się zaprowadzić porządek konstytucyjny, zapobiec rozpadowi kraju, umocnić władzę, ustabilizować gospodarkę, a także rozszerzyć i umocnić autorytet Rosji na arenie międzynarodowej ${ }^{6}$.

W zacytowanej narracji w sposób widoczny na pierwszy plan wysunięte zostały te motywy związane z rosyjską historią przełomu XX i XXI wieku, które współgrają z ideą budowy silnego, scentralizowanego państwa rosyjskiego, dążącego nade wszystko do odzyskania dawnej pozycji mocarstwowej.

Prześledźmy, w jaki sposób przytoczone refleksje korespondują z poglądami współczesnych Rosjan, ujawnionymi w sondażach opinii publicznej. Najwięcej, bo $81 \%$ Rosjan, czerpie informacje dotyczące wydarzeń w kraju i na świecie z rosyjskiej telewizji publicznej, podczas gdy z Internetu - zaledwie $40 \%$, a tylko $15 \%$ z gazet. Co ważne, $71 \%$ z nich wierzy, że telewizja publiczna przekazuje informacje w sposób obiektywny (dane z 2014 r.) $)^{7}$. W tym samym czasie jedynie co trzeci Rosjanin był przekonany o tym, że w Federacji Rosyjskiej istnieje rzeczywista opozycja polityczna, zaś osób uważających, że sposób, w jaki władze rozprawiają się z nią jest właściwy, było czterokrotnie więcej niż tych, wyrażających zdanie odmienne ${ }^{8}$.

Badania rosyjskiej opinii publicznej z połowy 2012 r., czyli z okresu ostatniej kampanii prezydenckiej w Rosji, która przeszła do historii za sprawą bezprecedensowej skali wystąpień obywateli przeciwnych ponownemu objęciu władzy przez Władimira Putina, wskazywały, że znacząca większość Rosjan

\footnotetext{
${ }^{5}$ R. Bäcker, Rosyjskie myślenie polityczne za czasów prezydenta Putina, Toruń 2007, s. 288-290.

${ }^{6}$ В.С. Измозик, О.Н. Журнвлева, С.Н. Рудник, История России, 9 класс, Москва 2015, s. 338.

${ }^{7}$ О перемирии на Украине и беженцах, http://fom.ru/Mir/11731 [dostęp: 1.06.2016].

${ }^{8}$ Политическая оппозиция, http://fom.ru/Politika/11785 [dostęp: 1.06.2016].
} 
albo nie znała czołowych przedstawicieli tzw. opozycji niesystemowej (takich jak Aleksiej Kudrin, Ilja Jaszyn, czy nawet Aleksiej Nawalny), albo odnosiła się do nich negatywnie, jak miało to miejsce zwłaszcza w przypadku znanej celebrytki Kseni Sobczak, Siergieja Udalcowa - lidera skrajnie lewicowego ruchu Awangarda Czerwonej Młodzieży, czy Eduarda Limonowa - kontrowersyjnego pisarza i przywódcy Partii Narodowo-Bolszewickiej ${ }^{9}$.

Prawie połowa obywateli Rosji (41\%) AD 2016 nie znała słów rosyjskiego hymnu, zaś prawie co trzeci $(27 \%)$ nie był w stanie wymienić spontanicznie ani jednego symbolu, z którym kojarzyłby mu się jego własny kraj. Co charakterystyczne, zaledwie $2 \%$ pytanych o ich skojarzenia związane z rosyjskością wymieniło czynniki takie jak historia, religia i kultura, czyli te źródła tożsamości, które świadczą o poczuciu zakorzenienia oraz oswojenia $\mathrm{z}$ tradycją i przeszłością. Ponad dwa razy więcej ankietowanych (5\%) wymieniło natomiast $\mathrm{w}$ tym kontekście nazwisko aktualnego prezydenta Rosji - Władimira Putina ${ }^{10}$.

Zgodnie z badaniami z 2013 r. postacią, która w opinii Rosjan najlepiej ucieleśnia cechy rosyjskiego charakteru narodowego jest Iwan-durak, dobry, niewinny i prostoduszny bohater rosyjskich przekazów ludowych. Nie bez powodu. Zdaniem respondentów Rosjan jako naród cechuje skłonność raczej do emocjonalnych niż racjonalnych zachowań, myślenie kategoriami wspólnoty, a także ufność i prostoduszność. Co ważne, wszystkie wymienione wartości stanowią niejako odbicie lustrzane postaw tradycyjnie kojarzonych z kulturą zachodnią, takich jak przyklaskiwanie wszystkiemu, co zgodne ze zdrowym rozsądkiem, wyrachowanie i egocentryzm ${ }^{11}$.

Rosjanie ankietowani przez Fundację Opinii Publicznej w 2013 r. stwierdzali, że ich zdaniem kultura i wartości wyznawane przez mieszkańców Rosji różnią się znacząco od tych, charakterystycznych dla obywateli zachodniej Europy. Przekonanie to wyraziło aż 57\% badanych, podczas gdy odmiennego zdania był zaledwie co dziesiąty. Odpowiedzi na pytanie o przejawy wspomnianych różnic ujawniły jednak silną ambiwalencję postaw Rosjan wobec Zachodu. Najwięcej obywateli wskazało na wyższy poziom stopy życiowej (15\%), a także kultury i wykształcenia (13\%) w krajach Europy Zachodniej, a także na inne zjawiska, które mogą stanowić podstawę do wysunięcia twierdzenia o istnieniu wśród Rosjan kompleksu cywilizacyjnej niższości, takie jak mający cechować Europejczyków silny patriotyzm, szacunek do własnej kultury, porządku społecznego i współobywateli. Co ciekawe, jedynie marginalny odsetek wypowiedzi stanowiły twierdzenia deprecjonujące zachodnich Europejczyków kosztem Rosjan. Przykładowo, nie więcej niż $2 \%$ pytanych wyraziło pogląd, że

\footnotetext{
${ }^{9}$ Российская оппозиция и дело Навального, http://fom.ru/Politika/10590 [dostęp: 1.06.2016].

${ }^{10}$ Символика России, http://fom.ru/TSennosti/12698 [dostęp: 1.06.2016].

${ }^{11}$ Русский характер, http://fom.ru/TSennosti/10971 [dostęp: 1.06.2016].
} 
Rosjanie przewyższają ich jakością życia duchowego, a także bezinteresownością, gościnnością (1\%), czy przywiązaniem do wartości rodzinnych (1\%). Równocześnie, zgodnie z wynikami tego samego sondażu, co trzeci Rosjanin (35\%) wyrażał obawy, że zachodni Europejczycy nie żywią pozytywnych uczuć w stosunku do Rosjan ${ }^{12}$.

Wreszcie, Rosjanie okazują się społeczeństwem mało wrażliwym na zagrożenia, jakie niesie z sobą współczesna ksenofobia, rasizm i nacjonalizm. Około połowa $\mathrm{z}$ nich podziela poglądy głoszone przez rosyjskich nacjonalistów, takie jak „Rosja dla Rosjan” (44\%) oraz „Koniec z karmieniem Kaukazu” (49\%; badanie z 2011 r.) $)^{13}$. Dwie trzecie Rosjan ankietowanych w 2014 r. przyznawało, że odczuwa lęk i nieufność wobec nielegalnych imigrantów przebywających w ich kraju, a co drugi z nich - niechęć na myśl, iż obóz dla nielegalnych imigrantów, w którym ci byliby przetrzymywani przed deportacją, mógłby zostać postawiony w ich regionie zamieszkania. Co ważne, zarówno zwolennicy tworzenia obozów, jak również krytycy wspomnianego projektu, na pytanie o swój stosunek do przybyszów w pierwszej kolejności odpowiadali, że jest ich w Rosji zbyt dużo, są zbędni i powinni zostać wydaleni. Jedynie co dziesiąty Rosjanin (8\%) zwracał uwagę na humanitarny aspekt związany z tworzeniem obozów dla imigrantów, przyznając, że dałyby im one możliwość stworzenia normalnych warunków do życia. Z drugiej strony większość, bo dwie trzecie Rosjan (63\%), było skłonnych zgodzić się na legalizację pobytu w Rosji tych imigrantów, którzy znają język rosyjski i nie mieli zatargów z prawem. Na pytanie o powód takiej opinii podawali jednak nade wszystko argumenty ekonomiczne. Ich zdaniem, imigranci powinni zapełnić lukę powstałą na rynku pracy, podejmując pracę w tych zawodach, na które nie ma popytu wśród miejscowych ${ }^{14}$.

Wprawdzie aż co trzeci mieszkaniec Rosji (29\%) ankietowany w 2013 r. przyznawał, że utrzymuje kontakty z osobami żydowskiego pochodzenia, jednak już tylko co szósty (16\%) deklarował krytyczny stosunek wobec osób propagujących poglądy antysemickie. $Z$ drugiej strony należy zauważyć jednak, że w ciągu ostatniego dziesięciolecia znacząco wzrosła liczba osób podzielających pogląd, iż poziom antysemityzmu w społeczeństwie rosyjskim spada, a nawet, że jest on mniejszy niż w Europie Zachodniej ${ }^{15}$.

\footnotetext{
${ }^{12}$ Россия и Европа, http://fom.ru/TSennosti/10957 [dostęp: 1.06.2016].

${ }^{13}$ Слова и славяне, http://fom.ru/Nastroeniya/10257 [dostęp: 1.06.2016].

${ }^{14}$ О нелегальных мигрантах. Лагеря или миграционная амнистия?, http://fom.ru/ob.shche stvo/ 11052 [dostęp: 1.06.2016].

${ }^{15}$ W 2005 r. odsetek osób uważających, że antysemityzm w Rosji jest większy niż w Europie Zachodniej oraz tych, twierdzących, że jest on tam mniejszy, był prawie jednakowy - wynosił odpowiednio 11 i 12\%, podczas gdy w 2013 r. - kolejno 7 i 15\%. Об отночении кевреям и антисемитам, http://fom.ru/obshchestvo/11188 [dostęp: 1.06.2016].
} 
Przytoczone dane potwierdzają tezę, iż współczesne społeczeństwo rosyjskie ma pozytywny stosunek do urzędującego prezydenta i głoszonej przez niego propagandy, nawet jeśli wiąże się z tym popadnięcie stan swoistej schizofrenii tożsamościowej, jest podatne na uleganie kompleksowi niższości i poczuciu pokrzywdzenia, a także przejawia skłonność do myślenia życzeniowego oraz niechęć do konfrontowania się z wszystkim tym, co reprezentuje szeroko rozumianą odmienność, obcość.

$\mathrm{W}$ rozdziale drugim dr Magdalena Żakowska analizuje motyw postradzieckiej apokalipsy obecny we współczesnej kinematografii rosyjskiej. Autorka śledzi specyfikę wspomnianych wątków na przykładzie kilku reprezentatywnych dzieł filmowych stworzonych przez wybitnych reżyserów rosyjskich, takich jak Iwan Wyrypajew (Tlen, 2009), Andriej Zwiagincew (Elena, 2011), Marina Lubakowa (Okrucieństwo, 2007), Wasilij Sigariew (Baczek, 2009) i Siergiej Łoźnica (Szczęście ty moje, 2010). Jednym z głównych tematów poruszanych w tle głównych rozważań zawartych $\mathrm{w}$ rozdziale są tezy o zbliżaniu się lub spełnianiu apokalipsy oraz refleksja na temat roli, jaką odegrały one w historii kultury rosyjskiej. Autorka podkreśla, iż motywy takie pojawiały się w dziejach Rosji wielokrotnie, zarówno w epoce przedpiotrowej, jak i w czasach bardziej współczesnych - na przełomie XIX i XX w., w okresie pierwszej wojny światowej, współcześnie zaś po rozpadzie ZSRR.

Co więcej, sposób rozumienia zmierzchu cywilizacji w myśli rosyjskiej znacząco różnił się od tego, jak postrzegali go intelektualiści zachodnioeuropejscy. Podczas gdy ci ostatni skupiali się na afirmowaniu schyłku europejskiej kultury, w Rosji - cytując słowa Joanny Wojnickiej - ,wskazywano raczej na zgliszcza po wielkim pożarze”. „Europejscy myśliciele - stwierdza Wojnicka - kokietowali śmiercią cywilizacji, rosyjscy artyści widzieli otchłań. Tam, gdzie ze strwożoną ciekawością oczekiwano na barbarzyńcę, Rosjan straszyła wizja azjatyckiej hordy. Wreszcie tam, gdzie z ulgą, w imię narodzin wyemancypowanego człowieka, żegnano starego Boga, Rosjanie widzieli nadciągający cień antychrysta" $"$. Drugim istotnym tematem poruszanym we wspomnianym tekście jest konstatacja, iż w historiozofii rosyjskiej tezy o zbliżającej się lub spełniającej apokalipsie są nieodłącznie powiązane z rozważaniami o chaosie, anarchii, społecznym buncie, przez co ten ostatni postrzegany jest nie tylko pesymistycznie, ale i w znacznym stopniu negatywnie - jako zwiastun społecznej i politycznej katastrofy. Apokalipsa utożsamiona jest $\mathrm{z}$ destrukcyjnymi działaniami, niszczącymi podstawy funkcjonowania społeczeństwa: przede wszystkim z łamaniem zasad

\footnotetext{
${ }^{16}$ J. Wojnicka, Apokalipsa naszych czasów, [w:] Autorzy kina europejskiego III, red. A. Helman i A. Pitrus, Kraków 2007, s. 155.
} 
więzi międzyludzkich, w tym norm seksualno-obyczajowych, w znacznie mniejszym stopniu zaś - $\mathrm{z}$ łamaniem prawa.

Co ważne jednak, tezy o buncie, apokalipsie, rozkładzie zdają się w kinematografii rosyjskiej nie dotykać przynajmniej jednej sfery życia - świata obecnej wielkiej polityki, władzy. Odpowiedź na pytanie o powód, dla którego w dzisiejszej kinematografii rosyjskiej brak jest krytycznej refleksji na temat świata współczesnej wielkiej polityki, zaś nieliczne filmy społeczne, poruszające problem korupcji na szczytach władzy, takie jak Lewiatan Andrieja Zwiagincewa spotykają się z polityczną nagonką, wykracza poza problematykę omawianego opracowania. Samo pytanie jednak bez wątpienia jednak warte jest postawienia.

Rozdzial trzeci porusza kwestię miejsca i roli kultury muzułmańskiej w wielokulturowej rzeczywistości Federacji Rosyjskiej. Począwszy od scharakteryzowania statusu prawnego islamu w Rosji oraz opisania zróżnicowania wyznaniowego i etnicznego społeczności muzułmańskiej w tym kraju, mgr Andrzej Stopczyński najwięcej uwagi poświęca zabiegom, podejmowanym zarówno przez muzułmańskie elity intelektualne, jak również przez elity rządzące, w celu budowania pozytywnego wizerunku i wspierania rozwoju tzw. tradycyjnego islamu. Wartość omawianego tekstu zasadza się w szczególności na spojrzeniu na rzeczywistość rosyjską z punktu widzenia obywateli Rosji, którzy jednocześnie utożsamiają się z kulturą muzułmańską i z wielokulturowym, Modernizującym się społeczeństwem euroazjatyckiego imperium.

Autor słusznie zwraca uwagę na fakt, iż wyzwanie, jakim jest dla władz Rosji wzrost $\mathrm{w}$ siłę nietradycyjnego, radykalnego islamu, w znaczącym stopniu zwiększa wagę działań, podejmowanych na rzecz opieki, umacniania i propagowania w Rosji ideologii związanej z umiarkowanymi nurtami religii muzułmańskiej. Niewątpliwie istotnym problemem jest również wykrystalizowanie się w latach dziewięćdziesiątych XX w. negatywnego wizerunku wyznawców Allaha zarówno w społeczeństwie, jak i w mediach, w których narracje o islamie i muzułmanach pojawiały się w kontekście wojen, ataków terrorystycznych i społecznych konfliktów.

Negatywny stosunek do muzułmanów wpisuje się też - co ważne - w ogólnorosyjski trend związany z postępującą ksenofobią. O ile jeszcze w roku 1989 do oznak ksenofobii przyznawało się zaledwie $20 \%$, to w 2001 r. liczba ta przekroczyła już $50 \%$ i nie wykazuje tendencji spadkowej ${ }^{17}$. W tym miejscu należy uwypuklić fakt, iż Federacja Rosyjska należy do szczególnej kategorii państw imigracyjnych. $Z$ jednej strony, w ciągu ostatnich lat kraj ten stał się państwem o największej liczbie imigrantów na świecie, zaraz po USA $(11,4 \mathrm{mln}$ w 2016 r., co stanowi 8\% mieszkańców). Przybysze stanowią ważny czynnik

\footnotetext{
${ }^{17}$ А. Малашенко, Ислам «легализованный» и возрожденный, [w:] Двадиать лет религиозной свободы в России, red. А. Малашенко, С. Филатов, Москва 2009, s. 53-63.
} 
wzrostu demograficznego Rosji w sytuacji, gdy - według prognoz - w ciągu kilkunastu lat populacja tego kraju skurczy się do $139 \mathrm{mln}$ (w momencie rozpadu ZSRR ludność RSFRR liczyła 148,7 mln), zaś gastarbeiterzy, będący nieodłącznym elementem krajobrazu rosyjskich metropolii, wytwarzają około $8 \%$ rosyjskiego PKB.

$\mathrm{Z}$ drugiej strony, efekty uboczne, związane z imigracją (gettoizacja, wzrost przestępczości), prowadzą do narastania w społeczeństwie ksenofobii wobec nie-Rosjan. Negatywny stosunek zwłaszcza do tzw. czarnych, czyli „dzikich” przybyszy z Kaukazu i Azji Środkowej, jest, co ważne, nie tylko powszechny, ale i powszechnie tolerowany w rosyjskim dyskursie politycznym, instytucjach publicznych i życiu codziennym, co stawia Rosję w negatywnym świetle w zestawieniu z wielokulturowymi krajami Europy Zachodniej, takimi jak Wielka Brytania czy Niemcy.

Autorka rozdziału czwartego, mgr Ewelina Chodakowska, porusza problematykę dialogu międzykulturowego, a wręcz zjawisko zafascynowania obcą kulturą, biorąc za punkt odniesienia obraz Syberii i Mandżurii w twórczości polskiego pisarza Igora Newerlego. Zarówno postać Newerlego, jak i przesłanie jego dzieł, stwarzają pole do interesujących refleksji nad regułami determinującymi literacką imagologię. Jak słusznie zauważa autorka,

artyści, którzy miejscem akcji swoich utworów czynią obszary inne niż rodzime, przyczyniają się do utwierdzania $\mathrm{w}$ danej kulturze pewnego zespołu wyobrażeń na temat obcych zbiorowości lub świadomie dążą do zakwestionowania ugruntowanych co do nich przekonań ${ }^{18}$.

Obraz Syberii zaś jest ciekawy o tyle, iż kraina ta zajmuje w kulturze polskiej miejsce szczególne, jako teren zesłania, kaźni, „lodowego piekła”, „ziemi przeklętej”. W przypadku Mandżurii również można wysunąć tezę, że choć kraina ta położona jest poza Europą, to jednak, zwłaszcza w XIX i na początku XX w. wywarła znaczący wpływ na historię, kulturę i tożsamość Polaków. Sposób przedstawienia owych „krain, gdzie nie ma nadziei” przez Newerlego jest natomiast wart prześledzenia ze względu na to, że w znaczącym stopniu łamie on schematy literackie związane z polską martyrologią.

Newerly urodził się w 1903 r. w Białowieży, wchodzącej wówczas w skład Rosji, w rodzinie o rosyjsko-czeskich korzeniach. Młodość spędził w Rosji, jednak od 1924 r. na stałe związał się z Polską. Przez wiele lat współpracował i przyjaźnił się z doktorem Januszem Korczakiem, którego dobry cień, jak przyznawał po

\footnotetext{
${ }^{18}$ E. Chodakowska, Wyobrażenie Syberii i Mandżurii w twórczości Igora Nawerlego, [w:] Europa swoich, Europa obcych. Stereotypy, zderzenia kultur i dyskursy tożsamościowe, red. M. Żakowska, A. Dąbrowska, J. Parnes, Łódź 2017, s. 77.
} 
latach, pozwolił mu nie zatracić człowieczeństwa nawet w obozie Auschwitz, zaś humanistyczne idee znalazły odzwierciedlenie w życiu (po wojnie Newerly został uhonorowany medalem Sprawiedliwy wśród Narodów Świata) i w powieściach.

Śledząc główne motywy narracyjne i przesłanie dwóch powieści Newerlego - Leśne Morze i Wzgórze Btękitnego Snu - nie sposób nie zgodzić się z autorką, iż zostały one w znaczący sposób naznaczone systemem wartości, wyznawanym przez Newerlego, w którym kluczowe miejsce zajmuje idea etnicznej i religijnej tolerancji. W obu powieściach stykamy się z motywem przezwyciężania różnic i obcości oraz bratania się pod jednym dachem (w przenośni i dosłownie) ludzi różnych narodowości: polskiej, rosyjskiej, żydowskiej - doświadczonych przez los i rzuconych na obce ziemie, ze sobą nawzajem i z przedstawicielami ludności rodzimej, surowej, żyjącej zgodnie z naturą, zarazem zaś gościnnej i życzliwej.

Choć krytycy zarzucali Newerlemu utopizm i nadmierną sielankowość, autorka tekstu słusznie zwraca uwagę, że świat przedstawiony w obu opisywanych powieściach miał dużo wspólnego z wielokulturową rzeczywistością rosyjskiego imperium, w którym, jak dowodzą tego pamiętniki polskich zesłańców, przedstawiciele różnych narodów nie tylko koegzystowali z sukcesem, lecz również szanowali się, przyjaźnili i żenili między sobą.

Lektura rozważań dotyczących twórczości Newerlego daje również możliwość wysnucia bardziej ogólnych konkluzji dotyczących fenomenu imagologii terytorialnej. Warto wiedzieć, że powstanie powieści Wzgórze Btękitnego Snu, opowiadającej o polskich zesłańcach na Syberii w okresie pierwszej wojny światowej, wiąże się z pobytem pisarza na kwaterze sybiraków na cmentarzu Powązkowskim i uczynioną wówczas refleksją, iż wspomniany fragment polskich dziejów nie znalazł dotąd należytego oddźwięku w literaturze ${ }^{19}$. Z kolei opowiadająca o życiu Polonii w Harbinie w latach II wojny światowej powieść Leśne Morze była dla Newerlego próbą ucieczki od polskiej rzeczywistości końca lat pięćdziesiątych, w szczególności zaś od wszechbecnego upolitycznienia twórczości literackiej, zaś jej dwa rozdziały - opowiadanie dwojga zbiegów z łagru i dyskusja o stalinizmie - zostały w wydaniu z 1960 roku usunięte przez cenzuręe ${ }^{20}$.

W ten sposób literacką peregrynację Newerlego po Syberii i Mandżurii, krainach, których nie dane mu było poznać inaczej niż za sprawą wyobraźni, można zinterpretować jako swoistą wyprawę na egzotyczne „wyspy szczęśliwe”, zarazem zaś jako powrót do świata bliskich mu, choć w znacznym stopniu zapomnianych wartości. W 1987 r., odbierając nagrodę za Wzgórze Btękitnego

\footnotetext{
${ }^{19}$ J. Zieliński, Szkatułki Newerlego, Warszawa 2012, s. 394.

${ }^{20}$ Tamże, s. 392.
} 
Snu, podkreślał wagę, jaką mają dla niego miłość, prawda, wolność, dzika, nieskażona przyroda, a także proste życie u boku drugiego człowieka: wartości bezcenne, lecz utracone na zawsze, o których - jak obawiał się sam Newerly - dziś można tylko pomarzyćc ${ }^{21}$.

\section{Lekcja Europy Środkowej}

Pierwszy z rozdziałów, zamieszczonych w części drugiej monografii, omawia ambiwalencje tożsamościowe oraz uwarunkowania społeczne leżące u źródeł postrzegania w społeczeństwie niemieckim i rosyjskim tzw. Niemców rosyjskich. Obok danych faktograficznych, związanych z historią i współczesnym statusem omawianej grupy społeczno-etnicznej, dr Magdalena Żakowska w swoim tekście zamieszcza szczegółowe informacje na temat obrazu Niemców rosyjskich, który obecny jest $\mathrm{w}$ niemieckim i rosyjskim stereotypie, w prasie i innych narracjach medialnych, a także jaki wyłania się na łamach literatury naukowej i popularnej oraz z wyników badań opinii publicznej.

Autorka, odwołując się do teorii orientalizmu Edwarda Saida, przytacza argumenty potwierdzające tezę, iż obraz omawianej grupy w społeczeństwie niemieckim naznaczony jest stygmatem uprzedzeń dotyczących dzikiego, zacofanego Wschodu. Obraz ten, choć stanowi dokładne przeciwieństwo nie tylko protestanckiego etosu tradycyjnie hołubionego przez tą społeczność, lecz również na wskroś pozytywnego wizerunku niemieckiej mniejszości etnicznej utrwalonego wśród Rosjan, można zdefiniować jako kalkę utrwalonego w niemieckim społeczeństwie stereotypu Rosjanina, równocześnie zaś jako dwuznaczny wzorzec dla młodszych pokoleń rosyjskich Niemców, żyjących w Republice Federalnej Niemiec.

W tym miejscu warto przywołać najnowsze dane statystyczne dotyczące wzajemnego postrzegania się Niemców i Rosjan. Rosjanie, pytani w 2013 r. o stosunek do poszczególnych krajów i narodów Europy Zachodniej, za szczególnie ważny punkt odniesienia uznali kraje takie jak Francja, Wielka Brytania, Włochy, przede wszystkim zaś Niemcy. Z jednej strony, określili oni RFN jako najbogatszy (38\% odpowiedzi) oraz najbardziej godny odwiedzenia kraj Europy (20\%), z drugiej zaś - paradoksalnie - jako to państwo kontynentu, którego mieszkańcy pod względem kultury, wyznawanych wartości i stylu życia są najbardziej podobni do Rosjan $(19 \%)^{22}$. W tym kontekście nie dziwią wyniki badań polskiego Instytutu Spraw Publicznych, w myśl których Niemcy są dla Rosjan również jedną z najbardziej lubianych nacji - sympatię wobec nich deklaru-

\footnotetext{
${ }^{21}$ Tamże, s. 7.

${ }^{22}$ Россия и Европа, http://fom.ru/TSennosti/10957 [dostęp: 1.06.2016].
} 
je aż co drugi mieszkaniec Federacji Rosyjskiej (55\%), zaś niechęć jedynie co dwunasty $(8 \% \text {, dane z } 2011 \text { r. })^{23}$. Dane dotyczące sposobu postrzegania Rosjan przez Niemców napawają już jednak mniejszym optymizmem. Badanie przeprowadzone w 2008 r. przez Forum Rosyjsko-Niemieckie wykazało, że antypatię wobec nich żywiło aż 35\% respondentów (przy sympatii deklarowanej przez $25 \%$ ankietowanych). Z kolei w przeprowadzonym niewiele później sondażu TNS EMNID do negatywnego stosunku względem Rosjan przyznał się wręcz co drugi mieszkaniec RFN $(49 \%)^{24}$.

Kolejny artykul, zamieszony w drugiej części pracy, analizuje ewolucję obrazu Austrii w prasie polskiej na przełomie XX i XXI w. Bazując na artykułach zamieszczonych w czasopiśmie „Polityka”, będącym od ponad pięćdziesięciu lat jednym z czołowych tygodników opiniotwórczych w naszym kraju, dr Jakub Parnes unaocznia istotną rolę, jaką w procesie demityzacji wizerunku Austrii odegrało wejście w 2000 r. do rządu kanclerza Wolfganga Schüssela skrajnie nacjonalistycznej Wolnościowej Partii Austrii (FPÖ), której liderem był Jörg Haider.

Autor, odwołując się do licznych tekstów prasowych ukazuje, niejako na marginesie głównych rozważań, jak dużą wagę współcześni polscy dziennikarze, intelektualiści, zaś poprzez nich i polska opinia publiczna przywiązują do wydarzeń związanych z II wojną światową i jej konsekwencjami. W polskim dyskursie prasowym, podobnie jak w polskiej polityce historycznej, wciąż, z narastającą siłą, powraca się do problemów takich jak geneza i istota nazizmu, fenomen zła, heroizmu, męczeństwa, ofiary oraz kwestia zagrożeń związanych ze społeczną amnezją.

Co więcej, w odróżnieniu od sytuacji, jaka miała miejsce w okresie PRL, gdy w historiografii polskiej obowiązywała interpretacja, zgodnie z którą Austriacy nie ponosili odpowiedzialności za działania III Rzeszy ${ }^{25}$, w rzeczywistości po $1989 \mathrm{r}$. zaistniała możliwość zainaugurowania nieuwarunkowanych ideologicznie rozważań na temat wątpliwego przebiegu denazyfikacji w Europie oraz nieuzasadnionej żywotności mitu Austrii jako pierwszej ofiary Hitlera. Rozważań, które na arenie międzynarodowej rozgorzały $\mathrm{w}$ związku z ujawnieniem w 1986 r. prawdy o za-

\footnotetext{
${ }^{23}$ J. Kucharczyk, A. Łada, C. Ochmann, Ł. Wenerski, Polityka i życie codzienne. Niemieckie spojrzenie na Polskę i Rosję, Warszawa 2013, s. 54-55.

${ }^{24}$ Tamże, s. 53.

25 Wymownym przykładem jest następujący cytat $\mathrm{z}$ jednej z książek popularnonaukowych, opublikowanych w 1987 r.: „Austria podminowana od wewnątrz przez podziemną jak i też legalną, jawną działalność austriackich nazistów, opuszczona przez świat, nie była zdolna przeciwstawić się hitlerowskiej agresji. Ze stoickim spokojem przyjął też ówczesny upadek Austrii świat zewnętrzny. Jedynym rządem, który odważył się wówczas, w marcu 1938 r. potępić włączenie siłą Austrii do Niemiec, był rząd Związku Socjalistycznych Republik Radzieckich, określając Anschluss jako akt agresji, a Austrię jako jej ofiarę”. F. Bernaś, Swastyka nad Wiedniem, Warszawa 1987 , s. 5.
} 
angażowaniu prezydenta Austrii i byłego sekretarza generalnego ONZ Kurta Waldheima w zbrodnie wojenne Wehrmachtu.

Opisywany rozdział daje również doskonały punkt odniesienia do refleksji na temat podobieństw i różnic $\mathrm{w}$ sposobie budowania narracji na temat różnych wydarzeń historycznych, w tym wypadku rozgrywających się w Austrii, w mediach i w świadomości społecznej w poszczególnych krajach Zachodu. Ciekawych wniosków dostarcza chociażby zestawienie poglądów na temat Wolnościowej Partii Austrii wyrażonych w omawianym okresie w Polsce i w USA. Wśród osób badanych za oceanem niepokój związany z dojściem do władzy Haidera wyraził w latach 1998-2000 r. co czwarty (23\%) z pytanych, podczas gdy w naszym kraju - co trzeci. Co więcej, badani z obu państw przejawiali zainteresowanie nieco innymi aspektami ideologii głoszonej przez FPÖ. W przypadku obywateli naszego kraju chodziło nade wszystko o skojarzenia z faszyzmem i niepokój przed nastaniem ery „nowego Hitlera”, w USA zaś o hasła neonazistowskie, ze szczególnym uwzględnieniem kwestii antysemityzmu ${ }^{26}$.

Nie sposób również przeoczyć charakterystycznych różnic w sposobie interpretowania austriackich wydarzeń w Polsce i w państwach zachodnioeuropejskich. W naszym kraju dyskusje o Jörgu Haiderze przybrały nade wszystko formę debat o współczesnym dziedzictwie nazistowskiej historii Austrii i Niemiec oraz rzucania światła na związane z nią „,białe plamy”. Natomiast w państwach takich jak Francja, Wielka Brytania, Niemcy czy sama Austria wspomniany dyskurs przybrał głównie formę rozważań o zagrożeniach, jakie dla całej współczesnej Europy niesie ze sobą ksenofobia, nietolerancja i populizm. Co więcej, badacze tacy jak Magali Perrault dyskusję na temat odradzającego się w Austrii nacjonalizmu wprzęgli w refleksje dotyczące obsesji związanych z narodową historią, podzielanej zwłaszcza przez narody Europy Środkowej. Dlatego, jak stwierdza wspomniana autorka,

dla przyszłości Europy Środkowej kluczowe znaczenie ma to, czy Austrii uda się uwolnić od cienia Haidera i powrócić do swoich kosmopolitycznych tradycji. Odegrałoby to pozytywną rolę w procesie ,powrotu do Europy” Węgier, Polski, Słowacji, Słowenii i Czech - nie wskutek dominacji politycznej lub gospodarczej, lecz w związku z bliskością kulturową krajów naddunajskich ${ }^{27}$.

\footnotetext{
${ }^{26}$ B. Roguska, Polacy o sytuacji politycznej w Austrii i integracji naszego kraju z Unia Europejska, Raport CBOS, 2000, nr 48, http://www.cbos.pl/SPISKOM.POL/2000/K_048_00.PDF [dostęp: 1.08.2016].

${ }^{27}$ M. Perrault, Trouble on the Island of the Blessed. The implications of the Austrian elections, „Central Europe's Review” 1999, nr 1, http://www.ce-review.org/99/16/perrault16.html [dostęp: 1.08.2016].
} 
Zacytowane słowa świadczą wyraźnie o ambiwalentnym stosunku znaczącej części intelektualistów zachodnioeuropejskich do zjawiska ,powracania do historii" i czynienia wysiłków na rzecz budowy spójnych narodowych etosów, które można zaobserwować obecnie w postkomunistycznych krajach Europy Środkowej. Z drugiej strony, podczas dyskusji dotyczących nazizmu w krajach takich jak Polska czy Rosja, będących sukcesorkami państw, które ucierpiały najbardziej w związku z podbojem przez III Rzeszę, pamięć o heroizmie i męczeństwie związanym z II wojną światową powoduje stawianie akcentu na jego ekskluzywne niemieckie (czy też zachodnioeuropejskie) podłoże. Analogicznie, w państwach tych dominującą reakcją na (wysuwane głównie przez zachodnie media i zachodnich intelektualistów) próby „kalania honoru” przodków lub strofowanie współczesnych ,postaw antyeuropejskich” jest często polemika bazująca na przypominaniu wydarzeń z przeszłości.

W rozdziale zamykającym drugą część naszej monografii dr Agata Dąbrowska omawia specyfikę wizerunku teatru żydowskiego w Polsce $\mathrm{w}$ prasie polskiej i żydowskiej, ukazującej się $\mathrm{w}$ dwudziestoleciu międzywojennym. Powołując się na liczne tytuły, oddające szerokie spektrum ówczesnych podziałów etnicznych i społecznych oraz opcji politycznych i światopoglądowych, autorka celnie unaocznia złożoność omawianej problematyki. Sposób postrzegania teatru żydowskiego w Polsce przed 1939 r. zależał bowiem nie tylko od aktualnego stanu relacji polsko-żydowskich, lecz nade wszystko - jak wykazuje autorka - był on następstwem silnych antysemickich stereotypów i uprzedzeń, szeroko rozpowszechnionych $\mathrm{w}$ społeczeństwie polskim. Co więcej, na negatywny obraz teatru żydowskiego rzutował pełen niechęci stosunek ortodoksyjnych środowisk społeczności żydowskiej wobec teatru w ogóle - traktowanego jako instytucja propagująca niską, prymitywną rozrywkę.

Pragnąc zrozumieć złożony charakter antysemickich postaw i nastrojów w naszej części Europy w omawianym okresie, należy przywołać towarzyszący im szerszy kontekst historyczny. Koniec XIX w. w całej Europie przyniósł wzrost nastrojów nacjonalistycznych, których charakter w społeczeństwie polskim nie różnił się zasadniczo od postaw dostrzeganych w tym czasie na przykład w społeczności żydowskiej, niemieckiej, czy ukraińskiej. Z założenia ideologii nacjonalistycznej, która postuluje budowę państw narodowych, jednolitych pod względem narodowościowym, wynika teza, iż we wspomnianym państwie nie ma miejsca dla obcych; muszą się oni albo zasymilować, albo znaleźć się poza organizmem państwowym ${ }^{28}$.

Już w pierwszych latach niepodległości nacjonaliści polscy twierdzili, że Żydzi są śmiertelnym zagrożeniem dla Polski, a ich poglądy zaostrzyły się

\footnotetext{
${ }^{28}$ M. Domagalska, Antysemityzm dla inteligencji? Kwestia żydowska w publicystyce Adolfa Nowaczyńskiego na łamach „, Myśli Narodowej” (1921-1934) i „Prosto z mostu” (1935-1939) (na tle porównawczym), Warszawa 2004, s. 15.
} 
jeszcze w latach trzydziestych. Jak można było przeczytać w Deklaracji Programowej Związku Młodych Narodowców z 1934 r., głosili oni ideę stworzenia Wielkiej Polski m.in. poprzez ,wyparcie trzech i pół miliona żydów z placówek, które oni zajmują i objęcie tych placówek przez żywioł polski” ${ }^{29}$. „Jako powód powyższych posunięć - pisze Małgorzata Domagalska - wskazywano rosnące bezrobocie, które dotykało młode pokolenie, ale zakres proponowanych działań znacznie wykraczał poza dziedzinę gospodarczą. Dążeniem polityki narodowej miało być: «stopniowe zmniejszanie siły liczebnej elementu żydowskiego w kraju przy równoczesnej ścisłej izolacji społeczeństwa polskiego od żydów w dziedzinie zarówno kulturalnej jak i społecznej, towarzyskiej i gospodarczej»” ${ }^{30}$. W 1933 roku, na łamach „Gazety Warszawskiej” i „Kuriera Poznańskiego”, w cyklu artykułów poświęconych kwestii żydowskiej, Roman Dmowski, dając wyraz swej obsesji, pisał:

Żydzi [...] mnożą się i umacniają wśród innych narodów świata, zdobywają wśród nich coraz większe wpływy, rozkładają ich siłę i zbliżają dzień ostatecznego zwycięstwa, zapanowania żydostwa nad światem, czasy, kiedy światem będą rządzili Mędrcy Syjonu ${ }^{31}$.

Hasła zacytowane wyżej brzmią szokująco dla współczesnego czytelnika, ich treść nie była jednak odbierana jako równie drastyczna w czasach, w których zostały one sformułowane. $\mathrm{W}$ głównych zarysach powielały one postulaty i twierdzenia, wpisujące się w dyskurs antysemicki, ukształtowany w formie ,naukowej” w Europie Zachodniej w XIX w. Nawet przytoczoną wyżej wypowiedź Romana Dmowskiego, opublikowaną $\mathrm{w}$ formie książkowej w zbiorze zatytułowanym Przewrót, uznać należy raczej za regułę niż wyjątek $w$ narracjach tworzonych $w$ ramach wspomnianego antysemickiego dyskursu.

Równocześnie dodać jednak należy, iż stosunek Polaków do mniejszości żydowskiej nacechowany był w wymienionym okresie również swoistą wschodnioeuropejską specyfiką. Po pierwsze, istotną rolę odgrywała znaczna, bezprecedensowa w skali europejskiej, liczebność wyżej wymienionej grupy. Drugą RP zamieszkiwało ok. 3 mln Żydów, stanowiących ok. 10\% polskiego społeczeństwa. Po drugie, ich społeczność była bardzo zróżnicowana, zarówno pod względem statusu społecznego, jak i światopoglądowym. Obok Żydów zasymilowanych i zeświecczonych istniały liczne, $\mathrm{z}$ reguły biedne społeczności Żydów ortodoksyjnych, których przetrwanie również stanowiło ewenement w po-

\footnotetext{
${ }^{29}$ Deklaracja Programowa Z.M.N., „Awangarda Państwa Narodowego” 1934, nr 5, cyt. za: M. Domagalska, dz. cyt., s. 31.

${ }^{30}$ Tamże, s. 31.

${ }^{31}$ R. Dmowski, Żydzi w dwudziesty wieku, [w:] tegoż, Przewrót, Warszawa 1934, s. 342, cyt. za: M. Domagalska, dz. cyt., s. 40-41.
} 
równaniu z sytuacją, jaka miała miejsce $\mathrm{w}$ Europie Zachodniej. Po trzecie, na ziemiach polskich rozpowszechniony był tzw. antysemityzm ludowy, silnie tkwiący $\mathrm{w}$ antyjudaizmie i odwołujący się do bezmyślnych, barbarzyńskich zachowań.

Siłą rzeczy więc niejednoznaczna i kręta historia społeczności żydowskiej en masse nie mogła nie odbić się niczym w soczewce w burzliwych dziejach teatru żydowskiego w naszym kraju. Nawet jednak mając w pamięci, iż omawiana instytucja miała trudną genezę i losy, zaś po 1939 r. bezpowrotnie umarła, warto przywracać pamięć o niej jako o ważnym symbolu związanym z wysiłkiem podjęcia dialogu kulturowego między narodem polskim i żydowskim.

\section{Meandry tożsamości narodowej i regionalnej}

Część trzecia naszej monografii zawiera teksty poświęcone specyfice tożsamości wybranych narodów oraz grup regionalno-etnicznych na naszym kontynencie. Ich szczególny walor polega na syntetycznym zestawieniu kluczowych wydarzeń historycznych, które wpłynęły na ukształtowanie wspomnianej tożsamościowej specyfiki, a także na umiejętnym wykazywaniu roli, jaką w procesie jej budowania odgrywały stereotypy i uprzedzenia dotyczące własnego i sąsiadujących narodów, a także narodowe mity oraz - nierzadko leżące $\mathrm{u}$ ich podłoża - wzorce kulturowe, ze szczególnym uwzględnieniem czterech wymiarów kulturowych wyodrębnionych przez holenderskiego psychologa społecznego Geerta Hofstede.

W pierwszym z rozdziałów mgr Aleksandra Małecka omawia różnice kulturowe oraz fakty historyczne, które w decydującym stopniu wpłynęły na ukształtowanie resentymentów w relacjach między Francuzami i Anglikami. Biorąc za punkt odniesienia wymiary kulturowe wyodrębnione przez Hofstede, takie jak dystans władzy, indywidualizm, męskość i unikanie niepewności, autorka wykazuje, iż w związku z ich specyfiką istniejącą w obu społeczeństwach można wyjaśnić zjawiska takie jak stopień przywiązania do własnej kultury, tożsamości narodowej i historii, podobnie jak skłonność do myślenia w kategoriach uniwersalistycznych lub polityczny pragmatyzm.

$\mathrm{Na}$ uwagę zasługują licznie przytoczone $\mathrm{w}$ artykule przykłady punktów spornych w sposobie pojmowania historii w Wielkiej Brytanii i Francji oraz konkluzja, nawiązująca do aforyzmu Williama Faulknera, iż „przeszłość nigdy nie umiera; właściwie nawet nie jest przeszłością".

Równocześnie, opisywany tekst w interesujący sposób skłania do głębszej refleksji na temat tego, dlaczego $\mathrm{w}$ rozpatrywanych relacjach francuskoangielskich to właśnie strona francuska zdaje się wykazywać większe nasilenie postaw odwołujących się do wzajemnych uraz, resentymentów i traum. Pouczające wnioski można wyciągnąc chociażby porównując kpiarsko-ironiczny dyskurs na temat wspomnianych problemów, który jest wyraźnie widoczny zwłasz- 
cza w popularnonaukowej literaturze brytyjskiej (za dobry przykład tej ostatniej posłużyć może tytuł i treść książki 1000 lat wkurzania Francuzów Stephena Clarke'a), przyprawiony silną nutą autoironii, z postawą znacznej części obywateli, polityków i intelektualistów francuskich, traktujących wspomniane problemy ze znacznie większą dozą patosu. Warto zauważyć, że właśnie obecność patetycznych narracji traktowana jest w psychologii jako syndrom, mogący świadczyć o wciąż niezagojonych traumach, kompensowanych fałszywym poczuciem wyższości ${ }^{32}$.

Zarówno w języku francuskim, jak i w angielskim, powstało mnóstwo bon motów sławiących wyższość francuskiego intelektu i stylu życia. W XIX w. Francuz Stendhal w powieści Czerwone $i$ czarne napisał, iż „talent i dowcip tracą z chwilą wylądowania w Anglii 25\% wartości”33, zaś w XX w. naturalizowany w Wielkiej Brytanii węgierski pisarz George Mikes stwierdził, że „na kontynencie ludzie mają życie seksualne, w Anglii - termofory do ogrzewania łóżka" ${ }^{34}$. Trudno natomiast o większą drażliwość niż ta, w jaką obfitują francuskie narracje dotyczące rodzimej historii. Charles de Gaulle, który po wojnie za swój nadrzędny cel uznał odbudowanie w narodzie francuskim dumy z własnej ojczyzny i rodaków, w chwilach, w których powątpiewał w możliwość odrodzenia narodowego mitu pisał, iż Francja wciąż , powraca do swoich błędów i wymiocin” oraz że on sam nie może ,zapobiec temu, by Francuzi byli Francuzami”,35.

Bardzo charakterystyczna jest skala różnic w narracjach o historii, zapisanych we współczesnych angielskich i francuskich podręcznikach. W tych pierwszych nacisk kładziony jest nade wszystko na poznawanie wydarzeń w sposób wieloaspektowy, przez pryzmat wychowania w duchu wartości takich jak krytyczne myślenie, wielokulturowość, różnorodność społeczna, kulturowa, religijna, etniczna, a także, last but not least, tolerancja ${ }^{36}$. W podręcznikach fran-

\footnotetext{
${ }^{32}$ Por. „Jeśli podstawowe potrzeby dziecka, by być zauważonym, by znaleźć potwierdzenie, przychylność i opiekę nie zostaną zaspokojone w wystarczający sposób, wycofuje się ono coraz bardziej, popadając w wyższościową izolację (splendid isolation), zgodnie z dewizą: «nikogo nie potrzebuję, jestem o wiele lepszy od tej osoby, od której miałbym oczekiwać miłości, jestem sam dla siebie ideałem»”. H.-P. Röhr, Narcyzm - zaklęte „ja”, Poznań 2007, s. 32-33, 168-176; P. Mamcarz, Strukturalna analiza właściwości podmiotowych w kontekście atrybucji oraz addytywności sytuacji traumatycznych, [w:] Interpersonalna trauma. Mechanizmy $i$ konsekwencje, red. A. Widera-Wysoczańska i A. Kuczyńska, Warszawa 2011, s. 77-86.

${ }^{33}$ Cyt. za: tamże, s. 369.

${ }^{34}$ Cyt. za: G. Mikes, How to Be an Alien: A Handbook for Beginners and More Advanced Pupils (1946), cyt. za: Księga cytatów czyli skarbczyk mądrości wszelkiej pelen, Czytelnikom dla nauki i rozrywki ofiarowany, red. I. Matusiak i J. Rohoziński, Warszawa 1999, s. 259.

${ }^{35}$ Cyt. za: S. Clarke, 1000 lat wkurzania Francuzów, thum. S. Kroszczyński, Warszawa 2012, s. 448.

${ }^{36}$ Por. K. Bradley, Contemporary Britain. Historical Insights: Focus on Teaching, Coventry 2010, s. 4-10; K. Hawkey, C. Morgan, Teaching 'The Romans' in an English Primary School Context,
} 
cuskich z kolei akcent kładziony jest na kształtowanie postaw etycznych i obywatelskich oraz znajomość faktografii, co nierzadko pociąga za sobą, jak przyznają badacze europejskich dyskursów edukacyjnych, skłonność do mitologizowania rodzimej historii ${ }^{37}$.

Rozdzial drugi omawia problematykę tożsamości kulturowej i narodowej współczesnych Portugalczyków. Autor, mgr Marcin Jurga, unaocznia w sugestywny sposób rolę, jaką w dzisiejszej Portugalii odgrywają mity historyczne, szczególnie zaś mit sebastiański, leżący od prawie pięciuset lat u podłoża portugalskich idei mesjańskich i imperialnych. Wartość omawianego tekstu zasadza się również na umiejętnym wpleceniu narracji dotyczących niepowtarzalności kulturowej mieszkańców tego kraju w rozważania na temat paraleli historycznych istniejących między Portugalią a Polską.

Wychodząc nieco poza kontekst zasadniczych rozważań, poruszanych w tekście, warto krótko odnieść się do obecności problematyki mesjańskiej w kontekście ogólnoeuropejskim. Wbrew przekonaniu nierzadko wyrażanemu przez Portugalczyków, idee mesjańskie, w tym przepowiednia dotycząca tajemniczego, przebywającego w ukryciu władcy, który pewnego dnia zdemaskuje wszelkie kłamstwa i zaprowadzi na całym świecie pokój, zostały ukształtowane nie tylko w Portugalii i nie tylko w XVI w. Mit o zaginionym i cudownie powracającym władcy, który w omawianym kraju przybrał postać legendy o królu Sebastianie, należy do najstarszych i najtrwalszych w całej cywilizacji chrześcijańskiej i śródziemnomorskiej. Pojawia się on już w biblijnych proroctwach Jeremiasza i Daniela, w średniowiecznym micie o królu Arturze, który ma powrócić z wyspy Avalon, w legendach o cesarzach takich jak Karol Wielki, Fryderyk Barbarossa (rzekomo ukryty gdzieś w górskiej pieczarze) czy Karol V (który pewnego dnia powróci z klasztornej samotni), a także syn Iwana Groźnego, carewicz Dymitr (który nie umarł w wieku chłopięcym, raniony nożem), czy król Polski i Węgier Władysław (który rzekomo uniknął śmierci w bitwie pod Warną) ${ }^{38}$. Z drugiej strony nie sposób odmówić słuszności badaczom, iż to właśnie mit o królu Sebastianie spośród wszystkich wymienionych zachował do chwili obecnej największą zdolność oddziaływania na świadomość narodu, który go zrodził.

Portugalia należy do tych specyficznych krajów w Europie, gdzie wciąż żywe są tradycje mesjańskie. Wyraźnie świadczy o tym skala recepcji w społeczeństwie coraz to nowych przesłań, nawiązujących do dziedzictwa sebastiańskiego. Ciekawym

[w:] Inter- and Intracultural Differences in European History Textbooks, red. C. Morgan, Bern 2005, s. 46-51.

${ }^{37}$ M. Chauveau, Algerian colonial history in French textbooks. At the crossroad of nationalism and memory clashes, praca magisterska obroniona na Erasmus University w Rotterdamie w 2013 r., s. $50,67,92$.

${ }^{38}$ H. Siewierski, Wstep, [w:] F. Pessoa, Mensagem = Przestanie, thum. A. da Silva i H. Siewierski, Warszawa 2006, s. 10. 
przykładem twórcy, który na początku XX w. tchnął nowego ducha w portugalski mesjanizm, był Fernando Pessoa, autor poematu Przestanie (Mensagem). W jednej z jego wciąż żywych i cytowanych strof zwerbalizował on tęsknotę (saudade) Portugalczyków skierowaną ku źródłom własnej tożsamości i narastającą wciąż w miarę oddalania się od nich. W swoich pieśniach pisał on o Portugalii jako o imperium, które w przeszłości było instrumentem Boga: jego ręką niosącą światło wiary, obecnie zaś jest już tylko „twarzą Europy” o spojrzeniu „sfinksowym i fatalnym”, czyli skierowanym na Zachód cieniem samej siebie ${ }^{39}$.

Co ważne, w zgodnej opinii dzisiejszych interpretatorów twórczości Pessoi, do realizacji mitycznego Piątego Imperium nie są konieczne kolonie, ponieważ ma to być imperium kultury, jednak sam sens tworzenia go nigdy nie powinien być stawiany w wątpliwość. Twarz Portugalii, państwa pozbawionego dawnej potęgi, biednego na tle unijnych towarzyszy, w pierwszym dziesięcioleciu XXI w. znajdującego się u progu finansowego kryzysu, powinna przejrzeć się - jak zauważa Henryk Siewierski - „w lustrze swego mitycznego źródła”, by nie Rozpłynąć się w melancholii teraźniejszości ${ }^{40}$.

Kolejny rozdzial, autorstwa Aleksandry Małeckiej, porusza bogate spektrum zagadnień związanych z budowaniem tożsamości narodowej Szkotów i współczesnym szkockim separatyzmem. Wśród tez, prezentowanych w pracy, na szczególną uwagę zasługują te, odnoszące się do kluczowej roli, jaką w kształtowaniu szkockiego etosu odegrała historia szkockiej państwowości oraz stałe kultywowanie pamięci o niej poprzez podręczniki historii, przekaz $\mathrm{w}$ rodzinie oraz kulturę masową41. We wnikliwy sposób artykuł omawia również zagadnienia związane z dualistyczną, szkocko-brytyjską tożsamością Szkotów.

Na uwagę zasługują diagnozy autorki dotyczące kulturowego podłoża, na którym ukształtowała się ,idea szkockości”. W artykule wysunięta została teza, iż wspomniana idea stanowi pochodną swoistego łączenia przeciwieństw. W „zaprogramowaniu kulturowym" Szkotów do głosu dochodzi zarówno indywidualizm, jak i silna orientacja grupowa, zarówno kult nauki, jak i duma z własnej historii i tradycji. Ciekawą ilustrację i kontekst dla wspomnianych rozważań stanowią słowa wypowiedziane u progu lat dziewięćdziesiątych XX w. przez wybitnego szkockiego patriotę, historyka Christophera Harvie:

Są rzeczy ważniejsze niż materialny dobrobyt, z powodu których uzyskanie przez Szkotów maksymalnej niezależności jest bardzo istotne. Jest raczej [...] naszą powinnością niż prawem, by brać udział w światowej polityce jako poważny naród, nie zaś jako jeden z regionów, pętających się z czapką w ręku po korytarzach w Bruk-

\footnotetext{
${ }^{39}$ F. Pessoa, Pole zamków, [w:] F. Pessoa, dz. cyt., Warszawa 2006, s. 25.

${ }^{40}$ H. Siewierski, dz. cyt., s. $12-14$.

${ }^{41}$ Por. R. Hill, My Europejczycy, thum. W. Sobiegraj, Warszawa 2004, s. 207.
} 
seli. [...] Podczas gdy dwie trzecie ludności świata tworzy społeczeństwa, które, zgodnie z terminologią Wall Street, są „mało rentowne”, my posiadamy doświadczenia i tradycje, mogące pomóc instytucjom światowym zmierzyć się z zagrożeniami, z którymi są stale konfrontowane. Posiadamy kontakty zarówno z Europą, jak i z Trzecim Światem, podobnie jak rozwinęliśmy szeroko zakrojone koncepcje dotyczące zrównoważonej ekologii i rozwoju na poziomie małych wspólnot, których działania nie są warunkowane pogonią za zyskiem czy zwodniczym nacjonalizmem"42.

Temat szkockiego separatyzmu jest współcześnie istotny oraz aktualny o tyle, iż kolejne dwa brytyjskie referenda: dotyczące niepodległości Szkocji (2014 r.) oraz wyjścia Zjednoczonego Królestwa z Unii Europejskiej (rok 2016) z dużym prawdopodobieństwem raczej zainaugurowały niż zamknęły proces brytyjskich zmagań z regionalizmem, separatyzmem i wielokulturowością ${ }^{43}$.

26 czerwca 2016 r., dwa dni po referendum, w którym głosami 51,9\% obywateli Wysp przesądzono sprawę Brexitu, autonomiczny rząd Nicoli Sturgeon ze Szkockiej Partii Narodowej (SNP) oświadczył, że postara się ,rozpocząć niezwłocznie rozmowy w Brukseli, by zabezpieczyć członkostwo Szkocji w Unii Europejskiej”“44. Niewątpliwie jednak wiele słuszności jest w stwierdzeniu autorki artykułu, iż pragmatyzm gospodarczy Szkotów jest przynajmniej równie silny jak ich uczucia narodowe. Niezależnie od tego, jak duże znaczenie ma dla szkockiego biznesu wymiana handlowa z krajami kontynentu, to jej znacząca większość, aż $65 \%$, odbywa się $\mathrm{w}$ ramach wymiany wewnętrznej w obrębie Wielkiej Brytanii ${ }^{45}$. Niezależnie też od radykalnych postaw reprezentowanych przez SNP, większość mieszkańców Szkocji pytanych o stosunek do idei niepodległości, wykazuje od lat znaczącą fluktuację postaw ze stopniowo nasilającym się obecnie wskazaniem na pozostanie częścią Zjednoczonego Królestwa nawet po przeprowadzonym ostatecznie Brexicie ${ }^{46}$.

W rozdziale wieńczącym monografię mgr Inessa Topala analizuje podłoże i specyfikę tożsamości regionalnej mieszkańców Donbasu. Ukraińska autorka

\footnotetext{
${ }^{42}$ Ch. Harvie, Cultural Weapons. Scotland and Survival in a New Europe, Edinburgh 1992, s. 109.

${ }^{43}$ Por. B.H. Toszek, Dewolucja jako element procesu dezintegracji państwowości brytyjskiej, [w:] Wspótczesne nacjonalizmy, pod red. M. Jezińskiego, Toruń 2008, s. 147-154.

44 M. Czarnecki, Premier Szkocji: Rozpoczynamy rozmowy w Brukseli, by pozostać w UE, $\mathrm{http} / /$ wyborcza.pl/1,75399,20302030,premier-szkocji-nicola-sturgeon-moj-rzad-rozpocznieniezwlocznie.html?disableRedirects=true [dostęp: 1.08.2016].

${ }^{45}$ A. Massie, Why Brexit Means Scottish Independence Is Off The Table - For Now, http://time. com/4390951/brexit-scottish-independence-barriers/ [dostęp: 1.08.2016].

${ }^{46}$ W końcu lipca 2016 r. stosunek osób opowiadających się za pozostaniem Szkocji w Zjednoczonym Królestwie do tych, wyrażających aspiracje niepodległościowe oraz pragnienie pozostania Szkocji w UE wynosił $46 \%$ do $37 \%$. M. Smith, Majority of Scots still favour staying in the UK after Brexit vote, https://yougov.co.uk/news/2016/07/30/brexit-fails-boost-support-scottish-ind ependence/ [dostęp: 1.08.2016].
} 
podkreśla doniosłą rolę, jaką w procesie kształtowania kultury i etosu omawianego regionu odegrała historia. Szczególną uwagę poświęca ona problematyce związanej z powstaniem i popularyzacją dwóch toposów: kozackiego, powiązanego z narracją dotyczącą Dzikich Pól, oraz górniczego, związanego z dyskursem o Donbasie jako krainie uosabiającej idee prężnej, nowoczesnej, bogatej i wielokulturowej społeczności pogranicza. Problematyka tożsamości mieszkańców Donbasu została też - co ważne - sprzężona z kwestią Ukrainy jako młodego państwa targanego przez pamięć o historycznych podziałach oraz regionalnych uprzedzeniach i resentymentach.

W tym miejscu warto odwołać się również do tez wysuwanych przez takich współczesnych badaczy jak Jarosław Hrycak, Marta Studenna-Skrukwa i Tomasz Stryjek. Hrycak określił Donbas mianem drugiego, po Galicji, centrum rozwoju ukraińskiej tożsamości narodowej. Lwów, stanowiący serce Galicji, swój nowoczesny status zawdzięczał roli administracyjnej i kulturowej, jaką uzyskał w czasach panowania Habsburgów. Natomiast Juzówka, protoplasta dzisiejszego Doniecka, rozwinęła się w wyniku boomu industrialnego, narastającego na południowowschodnich obrzeżach Rosji od końca XVIII w. ${ }^{47}$ W efekcie współczesna Galicja i Donbas reprezentują dwie odmienne wizje, względnie dwa odmienne „projekty” tworzenia ukraińskiego narodu.

Jak zauważa Studenna-Skrukwa, ,projekt” galicyjski wyrasta z koncepcji narodu, która - siłą rzeczy - zakłada funkcjonowanie państwa w oparciu o dominujący etnos tytularny, połączone z marginalizacją „obcych” komponentów historycznych, etnicznych i kulturowych. Z kolei u podłoża „,projektu” Donbasu leży - zdaniem wspomnianej badaczki - idea formowania nowoczesnego ukraińskiego narodu na podstawie zasady obywatelstwa, czyli przy założeniu prymatu więzi politycznych i gospodarczych nad etnicznymi i kulturowymi ${ }^{48}$.

Studenna-Skrukwa stwierdza również, iż eskalowaniu napięcia, czyli stopniowemu antagonizowaniu obu ,projektów” sprzyjają nade wszystko ukraińskie elity polityczne, dla których zróżnicowanie międzyregionalne stanowi podstawę „politechnologicznej mobilizacji elektoratu"49. Jak ujmuje to Anastazja Riabczuk, ,gdy myśli ludzi zaprząta debata na temat członkostwa w NATO, weteranów II wojny światowej, Kościoła czy stosunków z Rosją, ich uwaga nie skupia się na problemach

\footnotetext{
47 Я. Грицак, Формування модерної Украӥнскої наиії: історіографія та історіософія проблеми, autoreferat rozprawy habilitacyjnej, Instytut Archeologii i Źródłoznawstwa im. M. Hruszewskiego Ukraińskiej Akademii Nauk, Kijów 1996, cyt. za: M. Studenna-Skrukwa, Ukraiński Donbas. Oblicza tożsamości regionalnej, Poznań 2014, s. 76.

${ }^{48}$ M. Studenna-Skrukwa, Ukraiński Donbas. Oblicza tożsamości regionalnej, Poznań 2014, s. 77.

${ }^{49}$ Tamże, s. 88-89.
} 
bezrobocia, niskich płac, korupcji, ochrony środowiska czy opieki społecznej,"50, innymi słowy kwestie narodowe i regionalne mają w zamyśle polityków odwrócić uwagę obywateli od naprawdę istotnych zagadnien. W efekcie, status Ukrainy jako państwa, którego problemy tkwią głęboko w przeszłości, targanego podziałami o charakterze historycznym, pokrzywdzonego przez wieloletnią dominację z zewnątrz, staje się usprawiedliwieniem dla wszystkich bolączek, z jakimi boryka się ona współcześnie. Co więcej, „stałe odwoływanie się przywódców partii politycznych do wywołujących silne emocje newralgicznych zwrotów w historii zdaje się spełniać funkcję opium dla ludu" ${ }^{\text {. } 1}$.

Z kolei Tomasz Stryjek kładzie mocniejszy nacisk na polityczny kontekst rozwoju ukraińskich dyskursów historycznych i narodowych. Zauważa on, iż głównym czynnikiem, wpływającym ongiś na heroizację i mityzację przeszłości, był brak własnego, niepodległego państwa. Obecnie natomiast, po 1991 r., czynnikiem tym jest potrzeba spojenia owego państwa za pomocą silnych, pozytywnych etosów. $\mathrm{Z}$ tego właśnie względu, jak zauważa badacz, w narracjach historycznych na Ukrainie, niezależnie od tego, czy chodzi o Galicję, czy Donbas, dominuje motyw zbiorowego heroizmu oraz kreowania Ukraińców na naród ofiar ${ }^{52}$.

Radykalizacji nacjonalistycznych dyskursów nie towarzyszy jednak, paradoksalnie, analogiczna radykalizacja poglądów statystycznych mieszkańców Ukrainy. Patrząc bowiem z perspektywy Galicji lub Donbasu często zapomina się, że olbrzymia większość obywateli tego kraju to ludzie o płynnej tożsamości etnicznej, dwujęzyczni, wcielający w życie (często zapewne nieświadomie) idee zgodnej koegzystencji w społeczeństwie wielokulturowym. W tym kontekście warto podkreślić, że zgodnie z wynikami badań Pew Research Center, w 2014 r., tuż po aneksji Krymu, do negatywnych uczuć związanych z polityką Rosji przyznało się 81\% Polaków, około $71 \%$ Europejczyków $^{53}$ i zaledwie około $60 \%$ mieszkańców Ukrainy ${ }^{54}$. Co więcej, zasadniczo pozytywny stosunek tych ostatnich do Rosjan jako narodu nie zmienił się nawet po wybuchu wiosną 2014 r. wojny w Donbasie ${ }^{55}$.

Prognozy dotyczące przyszłości Donbasu są zagadnieniem, które siłą rzeczy wykracza poza ramy niniejszego opracowania. Podsumowując rozważania Dotyczące tożsamości i specyfiki omawianego regionu, warto jednak odnieść się do

\footnotetext{
${ }^{50}$ A. Riabczuk, Dwie Ukrainy, „Res Publica Nowa“ wiosna/lato 2008, s. 115-116, cyt. za: M. Studenna-Skrukwa, dz. cyt., s. 89.

${ }^{51}$ Tamże, s. $156-157$.

${ }^{52}$ Tamże, s. $345-346$.

${ }^{53} \mathrm{~W}$ kategorii tej nie uwzględniono poglądów Rosjan.

54 Choć w sierpniu 2015 r. było to już $72 \%$. Opinion of Russia Largely Unfavorable, http://www.pewglobal.org/2015/08/05/russia-putin-held-in-low-regard-around-the-world/russiaimage-08/ [dostęp: 15.08.2016]; Russia's Global Image Negative amid Crisis in Ukraine, http://www.pewglobal.org/2014/07/09/russias-global-image-negative-amid-crisis-in-ukraine/ [dostęp: 15.08.2016].

${ }^{55}$ T. Stryjek, Ukraina przed końcem Historii. Szkice o polityce państw wobec pamięci, Warszawa 2014, s. 37.
} 
opinii, które na temat jego dalszych losów wypowiedzieli, znajdując się, jak można przypuszczać, w znacznym stopniu pod wpływem propagandy kremlowskiej, Rosjanie. Co trzeci z nich wyrażał w 2014 r. przekonanie, że separatystyczne Republiki Doniecka i Ługańska w przyszłości odłączą się od Ukrainy i uzyskają pełną niezależność, zaś co czwarty - że wejdą one w skład Federacji Rosyjskiej $^{56}$. Niezależnie od tego, jak ostatecznie zakończy się konflikt, zakładając natomiast, iż wspomniane prognozy wyrażały nie tylko poglądy, lecz również nadzieje statystycznych Rosjan, można sformułować konkluzję, iż region Donbasu, łącznie $\mathrm{z}$ jego tożsamością i etosem, jest terytorium, na którym skumulowane są silne emocje i który urósł do rangi politycznego, względnie narodowego symbolu nie tylko dla mieszkańców Ukrainy.

Współczesne hasła związane z budowaniem, odkrywaniem lub reaktywowaniem wspólnotowych tożsamości, które dają o sobie znać z wielorakim nasileniem w całej Europie, można oceniać z różnych perspektyw. Autorzy niniejszego tomu nie stawiają sobie za cel nadawać im jednoznacznych ocen. Jednego jesteśmy natomiast pewni. Niezależnie od tego, czy współczesne ruchy narodowo-etniczne należałoby doceniać za przywracanie lub utrwalanie ducha wspólnoty, walkę o historyczną pamięć i prawdę oraz za hasła powrotu do korzeni, czy też potępiać za wyolbrzymianie znaczenia kulturowych i narodowych różnic oraz petryfikowanie poczucia „odwiecznej” inności, wyższości lub krzywdy własnej grupy lub narodu, co w efekcie prowadzić może do zaściankowości, nacjonalizmu i ksenofobii ${ }^{57}$, nie da się zaprzeczyć diagnozie postawionej przez amerykańskiego antropologa Davida Maybury-Lewisa, iż „etniczność nie znika w nowoczesnych państwach", zaś u progu XXI wieku jesteśmy świadkami jej utwierdzania ${ }^{58}$.

\footnotetext{
${ }^{56}$ O перемирии на Украине и беженцах, http://fom.ru/Mir/11731 [dostęp: 1.06.2016].

${ }^{57}$ Por. R. Kapuściński, Ten Inny, Kraków 2007, s. 38.

${ }^{58}$ Cyt. za: E. Lewandowski, Pejzaż etniczny Europy, Warszawa 2004, s. 5.
} 


\section{Bibliografia}

Aleksijewicz S., Czasy secondhand. Koniec czerwonego człowieka, Wołowiec 2015.

Bäcker R., Rosyjskie myślenie polityczne za czasów prezydenta Putina, Torun 2007.

Bernaś F., Swastyka nad Wiedniem, Warszawa 1987.

Bradley K., Contemporary Britain. Historical Insights: Focus on Teaching, Coventry 2010.

Chauveau M., Algerian colonial history in French textbooks. At the crossroad of nationalism and memory clashes, praca magisterska obroniona na Erasmus University w Rotterdamie w $2013 \mathrm{r}$.

Chodakowska E., Wyobrażenie Syberii i Mandżurii w twórczości Igora Newerlego, [w:] Europa swoich, Europa obcych. Stereotypy, zderzenia kultur i dyskursy tożsamościowe, red. M. Żakowska, A. Dąbrowska, J. Parnes, Łódź 2017.

Clarke S., 1000 lat wkurzania Francuzów, thum. S. Kroszczyński, Warszawa 2012.

Czarnecki M., Premier Szkocji: Rozpoczynamy rozmowy w Brukseli, by pozostać w UE, http:// wyborcza.pl/1,75399,20302030,premier-szkocji-nicola-sturgeon-moj-rzad-rozpocznie-niezw locznie.html?disableRedirects=true [dostęp: 1.08.2016].

Deklaracja Programowa Z.M.N., „Awangarda Państwa Narodowego” 1934, nr 5.

Dmowski R., Żydzi w dwudziesty wieku, [w:] tegoż, Przewrót, Warszawa 1934.

Domagalska M., Antysemityzm dla inteligencji? Kwestia żydowska $w$ publicystyce Adolfa Nowaczyńskiego na tamach „Myśli Narodowej” (1921-1934) i „Prosto z Mostu” (1935-1939) (na tle porównawczym), Warszawa 2004.

Eliade M., Mity, sny i misteria, thum. K. Kocjan, Warszawa 1994.

Gnoza polityczna, red. J. Skoczyński, Kraków 1998.

Harvie Ch., Cultural Weapons. Scotland and Survival in a New Europe, Edinburgh 1992, s. 109.

Hawkey K., Morgan C., Teaching 'The Romans' in an English Primary School Context, [w:] Inter- and Intracultural Differences in European History Textbooks, red. C. Morgan, Bern 2005.

Hill R., My Europejczycy, thum. W. Sobiegraj, Warszawa 2004.

Kapuściński R., Ten Inny, Kraków 2007.

Księga cytatów czyli skarbczyk mądrości wszelkiej peten, Czytelnikom dla nauki i rozrywki ofiarowany, red. I. Matusiak i J. Rohoziński, Warszawa 1999.

Kucharczyk J., Lada A., Ochmann C., Wenerski L., Polityka i życie codzienne. Niemieckie spojrzenie na Polskę i Rosję, Warszawa 2013.

Lewandowski E., Pejzaż etniczny Europy, Warszawa 2004.

Mamcarz P., Strukturalna analiza właściwości podmiotowych $w$ kontekście atrybucji oraz addytywności sytuacji traumatycznych, [w:] Interpersonalna trauma. Mechanizmy i konsekwencje, red. A. Widera-Wysoczańska i A. Kuczyńska, Warszawa 2011.

Massie A., Why Brexit Means Scottish Independence Is Off The Table - For Now, http://time. com/4390951/brexit-scottish-independence-barriers/ [dostęp: 1.08.2016].

Mikes G., How to Be an Alien: A Handbook for Beginners and More Advanced Pupils, London 1946.

Opinion of Russia Largely Unfavorable, http://www.pewglobal.org/2015/ 08/05/russia-putin-heldin-low-regard-around-the-world/russia-image-08/ [dostęp: 15.08.2016].

Perrault M., Trouble on the Island of the Blessed. The implications of the Austrian elections, „Central Europe's Review" 1999, nr 1, http://www.ce-review.org/99/16/perrault16.html [dostęp: 1.08.2016].

Pessoa F., Mensagem = Przestanie, thum. A. da Silva i H. Siewierski, Warszawa 2006.

Riabczuk A., Dwie Ukrainy, „Res Publica Nowa” wiosna/lato 2008. 
Roguska B., Polacy o sytuacji politycznej w Austrii i integracji naszego kraju z Unia Europejska, Raport CBOS, 2000, nr 48, http://www.cbos.pl/SPISKOM. POL/2000/K_048_00.PDF [dostęp: 1.08.2016].

Röhr H.-P., Narcyzm - zaklęte ,ja”, Poznań 2007.

Russia's Global Image Negative amid Crisis in Ukraine, http://www.pewglobal. org/2014/07/09 /russias-global-image-negative-amid-crisis-in-ukraine/ [dostęp: 15.08.2016].

Smith M., Majority of Scots still favour staying in the UK after Brexit vote, https://yougov. co.uk/news/2016/07/30/brexit-fails-boost-support-scottish-independence/ [dostęp: 1.08.2016].

Stryjek T., Ukraina przed końcem Historii. Szkice o polityce państw wobec pamięci, Warszawa 2014.

Studenna-Skrukwa M., Ukraiński Donbas. Oblicza tożsamości regionalnej, Poznań 2014.

Toszek B.H., Dewolucja jako element procesu dezintegracji państwowości brytyjskiej, [w:] Wspótczesne nacjonalizmy, pod red. M. Jezińskiego, Toruń 2008.

Wojnicka J., Apokalipsa naszych czasów, [w:] Autorzy kina europejskiego III, red. A. Helman i A. Pitrus, Kraków 2007.

Zieliński J., Szkatutki Newerlego, Warszawa 2012.

Грицак Я., Формування модерної Украӥнскої нації: історіографія та історіософія проблемu, autoreferat rozprawy habilitacyjnej, Instytut Archeologii i Źródłoznawstwa im. M. Hruszewskiego Ukraińskiej Akademii Nauk, Kijów 1996.

Измозик В.С., Журнвлева О.Н., Рудник С.Н., История России, 9 класс, Москва 2015.

Малашенко А., Ислам «легализованный» и возрожденный, [w:] Двадиать лет религиозной свободы в России, red.А. Малашенко, С. Филатов, Москва 2009.

О нелегальных мигрантах. Лагеря или миграџионная амнистия?, http://fom.ru/obshches tvo/11052 [dostęp: 1.06.2016].

О перемирии на Украине и беженцах, http://fom.ru/Mir/11731 [dostęp: 1.06.2016].

Об отношении кевреям и антисемитам, http://fom.ru/obshchestvo/11188 [dostęp: 1.06.2016].

Политическая оппозиция, http://fom.ru/Politika/11785 [dostęp: 1.06.2016].

Российская оппозиция и дело Навального, http://fom.ru/Politika/10590 [dostęp: 1.06.2016].

Россия и Европа, http://fom.ru/TSennosti/10957 [dostęp: 1.06.2016].

Россия и Европа, http://fom.ru/TSennosti/10957 [dostęp: 1.06.2016].

Русский характер, http://fom.ru/TSennosti/10971 [dostęp: 1.06.2016].

Символика России, http://fom.ru/TSennosti/12698 [dostęp: 1.06.2016].

Слова и славяне, http://fom.ru/Nastroeniya/10257 [dostęp: 1.06.2016]. 